formation on the question of conduction of nerve impulses or the release of noradrenaline in the peripheral adrenergic nerve. Results obtained by other investigators have suggested the possibility that lithium ions decrease the level of noradrenaline at the receptor sites (2) or the content of noradrenaline itself (3) in the brain. Katz and Kopin (4) have demonstrated a lithium-induced inhibition of noradrenaline- ${ }^{3} \mathrm{H}$ release evoked by electrical stimuli, being prevented by raising the concentration of calcium, in brain slices from rats. As demonstrated in Table 1, however, atrial responses to exogenously applied noradrenaline were reduced by $14.3 \mathrm{mM}$ lithium ions, the concentration of which produced no depression of the contractile rate and force, at a time when the blockade of transmission was fully established. Decreases in responses to noradrenaline were in parallel with the blockade of transmission. These results resemble the findings obtained in the sympathetic ganglia of cats, that when $\mathrm{NaCl}$ was replaced by $\mathrm{LiCl}$, the ganglionic depolarization evoked by acetylcholine was decreased in parallel with transmission (6).

It can be concluded that a major mechanism of the blockade of adrenergic transmission induced by lithium chloride is derived from the decrease in the sensitivity of the atrial postsynaptic membrane 10 noradrenaline.

Acknowledgment: The authors are grateful to Mr. Keiji Hirai for technical assistances.

\title{
REFERENCES
}

1) Schou, M.: J. Psychiat. Res. 6, 67 (1968); 2) Schildkradt, J.J., Schanberg, S.M. and Kopin, I.J.: Life Sci. 5. 1479 (1966); 3) CORRod, H., FuXr, K., Hö́fElt, T. and Schou, M.: Psychopharmacol. 11, 345 (1967); 4) KATZ, R.I. AND KoPIN, I.J.: Biochem. Pharmacol. 18, 1935 (1969); 5) Misu, Y. Avo KiRPeKar, S.M.: J. Pharmacol. exp. Ther. 163, 330 (1968); 6) Pappano, A.I. and Yolle, R.L.: $J$. Pharmacol exp. Ther. 157, 346 (1967)

\section{FETAL HYPOPROTEINEMIA ASSOCIATED WITH GENERALIZED EDEMA CAUSED BY ADMINISTRATION OF METHYL XANTHINES TO THE RAT DURING LATE PREGNANCY}

\author{
Takaki FUJII and Hideo NISHIMURA* \\ Research Laboratories, Nippon Merck-Banyu Co., Ltd., Okazaki, Aichi-ken, Japan \\ and Department of Anatomy, Faculty of Medicine, Kyoro University, Kyoto, Japan*
}

Accepted July 10, 1973

In a previous experiment (1), it wits found that a high incidence of generalized edena of the fotus resulted when a dict containing $0.50 \%$ of calleme wats given to pregnant rats during the last week of gestation. An investigation was thus undertaken as 10 whether or not two other methyl xanthines, theophylline and theobromine have a similar effect on rat fetuses when the mothers are given same under similar conditions as was caffeine. 
Sprague-Dawley rats purchased from Japan CLEA Co. at 4 weeks of age were reared and conditioned to animal room environment of N.M.B. Research Laboratories for 6 weeks. Females were mated overnight $(17 \mathrm{hr})$ with an adult male of the same strain. Copulation was established by the presence of spermatozoa in the vaginal smear. On this day, designated as day 1, pregnant animals were divided into 7 groups each and diets were given as follows. Group CF-0.4; a diet containing $0.40 \%$ of cafreine during the period from day 15 to 20 of gestation. Group TP-0.4; a diel containing $0.40 \%$ of theophylline during the same period. Group TP-0.6; a diet containing $0.60 \%$ of theophylline during the same period. Group TB- 0.4 ; a diet containing $0.40 \%$ of theobromine during the same period. Group TB- 0.8 ; a diet containing $0.80 \%$ of theobromine during the same period. Control group I; the basal powdered diet ad libitum. Control group II; the basal powdered diet at $40 \mathrm{~g} / \mathrm{kg} / \mathrm{day}$ from day 15 to 20 of gestation. During the rest of gestation, all females were allowed free access to a basal solid diel. Fresh tap water was given ad libitum throughout pregnancy. Food consumption and body wt. of the animals of all groups were recorded daily during the treatment period. All pregnant rats were sacrificed on day 21 of gestation. The utcrus was incised and examined for implantation sites, resorptions and dead fetuses. Live fetuses were removed from the uterus, weighed and examined for extemal abnormalities. In addition, about $50 \mu l$ of umbilical blood was drawn on several live fetuses of each litter immediately after removal of the placenta and was placed for measurements of plasma protein by means of a refractometer.

With the purpose of assessing the degrec of fetal edema, all the live fetuses were dried in a oven at $110 \pm 5^{\circ} \mathrm{C}$ for $6 \mathrm{hr}$ and total body water was recorded for each fetus as percentage.

Average food consumption and drug intake as well as autopsy findings are shown in Table 1. Average daily food consumption was decreased in all the treatment groups and particularly in the theophylline groups. It was noted that such a decrease was most remarkable on the first day of administration. External toxic signs were not observed macroscopically except that depilation of the abdominal hair was occasionally observed

TABLE 1. Effects on fetal development when methyl xanthines are mixed into a diet and given to pregnant rats during the last week of gestation

\begin{tabular}{ccccccc}
\hline & \multicolumn{5}{c}{ Embryos } \\
Group & $\begin{array}{c}\text { No. } \\
\text { animals }\end{array}$ & $\begin{array}{c}\text { Average food } \\
\text { consumption } \\
(\mathrm{g} / \mathrm{kg} / \mathrm{day})\end{array}$ & $\begin{array}{c}\text { Average drug } \\
\text { intake } \\
(\mathrm{ng} / \mathrm{kg} \text { day })\end{array}$ & $\begin{array}{c}\text { Total } \\
\text { implants }\end{array}$ & $\begin{array}{c}\text { No, of } \\
\text { resorptions } \\
(0 / 0)\end{array}$ & $\begin{array}{c}\text { Average body } \\
\text { weight } \\
\text { S.E. }\end{array}$ \\
Control I & 9 & 78.1 & $\ldots$ & 120 & $6(5.0)$ & $3.61 \pm 0.029^{+}$ \\
Control II & 11 & 40.0 & $\ldots$ & 137 & $5(3.6)$ & $3.47 \pm 0.027^{*}$ \\
CF-0.4 & 9 & 53.4 & 213 & 123 & $9(7.3)$ & $3.52 \pm 0.037^{* *}$ \\
TP-0.4 & 8 & 41.4 & 165 & 114 & $11(9.6)$ & $3.57 \pm 0.039^{++}$ \\
TP-0.6 & 9 & 41.5 & 249 & 133 & $8(6.0)$ & $3.31 \pm 0.038^{*+}$ \\
TB-0.4 & 8 & 72.5 & 290 & 95 & $9(9.5)$ & $3.24 \pm 0.033^{*+}$ \\
TB-0.8 & 8 & 58.9 & 471 & 107 & $2(1.9)$ & $3.15 \pm 0.030^{*+}$ \\
\hline
\end{tabular}

+ or ++ : Significantly different from that of control II at $\mathrm{P}<0.01$ or $\mathrm{P}<0.05$

* or **: Significantly different from that of control I at $\mathrm{P}<0.01$ or $\mathrm{P}<0.05$ 
in the calfeine and theophylline groups. Table 1 denonstrates that a significant increase of resorptions was not cvident with either diet restriction or drug administration. The average body wt. of fetuses in groups TP-0.6, TB-0.4 and TB-0.8 was significantly lowered compared to both the control groups. In group CF-0.4, the average wt. was significantly decreased compared to that of Control I, but not to Control II. The average wt. of group TP-0.4 was not affected by the treatment.

TABLE 2. Total body water and plasma protein of rat fetuses from mothers given methyl xanthines during the last week of gestation

\begin{tabular}{ccccc}
\hline Group & $\begin{array}{c}\text { Average total } \\
\text { body water } \\
\pm \text { S.E. }(\%)\end{array}$ & $\begin{array}{c}\text { No. fetuses with T.B.W.** } \\
\text { over 88\% of body weight } \\
\text { and frequency }(\%)\end{array}$ & $\begin{array}{c}\text { Average total } \\
\text { plasma protein } \\
\pm \text { S.E. (g'dl) }\end{array}$ & $\begin{array}{c}\text { Assayed } \\
\text { samples }\end{array}$ \\
Control I & $86.2 \pm 0.071^{+}$ & 0 & $2.88 \pm 0.025^{+}$ & 45 \\
Control II & $87.0 \pm 0.050^{*}$ & $1(0.8)$ & $2.69 \pm 0.031^{*}$ & 59 \\
CF-0.4 & $88.1 \pm 0.070^{*+}$ & $57(50.0)$ & $2.38 \pm 0.031^{*+}$ & 57 \\
TP-0.4 & $86.9 \pm 0.103^{*}$ & $13(12.6)$ & $2.61 \pm 0.036^{*}$ & 38 \\
TP-0.6 & $87.6 \pm 0.051^{*+}$ & $24(19.2)$ & $2.42 \pm 0.056^{*+}$ & 40 \\
TB-0.4 & $87.6 \pm 0.082^{*+}$ & $26(30.2)$ & $2.26 \pm 0.029^{*+}$ & 35 \\
TB-0.8 & $89.1 \pm 0.050^{*+}$ & $105(100)$ & $2.03 \pm 0.039^{*+}$ & 37 \\
\hline
\end{tabular}

$f$ : Significantly different from that of Control II at $\mathrm{P}<0.01$

* : Significantly different from that of Control I at $\mathbf{P}<0.01$

**: Total body water

The number of fetuses with the content of tolal body water over $88 \%$ and the content of total plasma protcin are listed in Table 2. In groups CF-0.4, TP-0.6, TB-0.4 and TB-0.8, the average content of total body water was significantly higher compared to those of both control groups. In group TP-0.4, the content was significantly higher than that of Control I, but not different compared to Control Il. The number of fetuses with total body water over $88^{\circ}$, of body w. was significantly increased in all treatment groups compared to both control groups. The total plasma protein of fetuses in groups CF-0.4, TP0.6, TB-0.4 and TB-0.8 was significantly lowered as compared with that in both control groups. In group TP-0.4, total plasma protein was significantly decreased compared to that of Control 1, but not to Control Il.

Each female of Control group 11, where daily food consumption was limited to 40 $\mathrm{g} / \mathrm{kg}$, consumed the food within a few hr and ingested nothing thereafter. This condition also had an effect on the total body water and plasma protein of the fetuses. In view of these findings, it is presumed that the results shown in the feluses of the groups treated with cither of caffeine and theophylline may be due to the combined effects of slight starvation and the compounds administered. It should be noted, however, that in group TB0.4 , in which the consumed diet was alnost same as control group $\mathbf{I}$, severe changes were noted in their fetuses. It can be concluded that all these methyl xanthines cause fetal hypoproteinemia and edena whon they are given to pregnant rats during late gestation.

\section{REFLRENCE}

1) Fujl, T. A.jD Nishimura, H.: Toxicol. appl. Phamacol. 22, 449 (1972) 